\title{
Convergent and Divergent Aspects of Social Work and Social Pedagogy
}

\author{
Andrej Mátel ${ }^{1}$ \\ Andrea Preissová \\ Krejči ${ }^{2}$
}

\section{Contacts to authors}

${ }^{1}$ College of Health and Social Work of St. Elizabeth, Palackého No. 1, P.O.BOX 104, 81000 Bratislava andrej.matel@gmail.com

2 Palacky University in Olomouc, Faculty of Education, Žižkovo nám. 5, 77140 Olomouc andrea.preissova@upol.cz

\section{Kontakty na autory}

${ }^{1}$ Vysoká škola zdravotníctva a sociálnej práce sv. Alžbety, Palackého č. 1, P.O.BOX 104, 81000 Bratislava andrej.matel@gmail.com

2 Univerzita Palackého v Olomouci, Pedagogická fakulta, Žižkovo nám. 5, 77140 Olomouc andrea.preissova@upol.cz

Copyright (C) 2016 by authors and publisher TBU in Zlín. This work is licensed under the Creative Commons Attribution International License (CC BY).

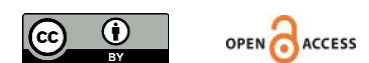

\begin{abstract}
The study in hand aims to identify convergent and divergent aspects of social work and social pedagogy through the means of content analysis and comparison. The research sample consists of scientific and specialised texts written in Slovak, Czech, German, and English with emphasis on defining both disciplines and prioritizing the Slovak and Czech language area. The study identifies convergent and divergent aspects of social work and social pedagogy as two unique disciplines and professions. The authors incline towards the view that social pedagogy is more theoretical and general, while social work is a practical and applied science. However, intensive mutual cooperation is equally important for both disciplines aiming primarily at preventing socially pathological phenomena in society and thus leading to a healthy physical, psychological and social development of the individual.
\end{abstract}

Key words: divergence, convergence, social functioning, social pedagogy, social work

\section{Konvergentní a divergentní prvky sociální práce a sociální pedagogiky}

\begin{abstract}
Abstrakt: Cílem studie je identifikování konvergentních a divergentních prvků sociální práce a sociální pedagogiky prostřednictvím obsahové analýzy a komparace. Výzkumný soubor tvoří vědecké a odborné texty slovensky, česky, německy nebo anglicky piśících autorů, s důrazem na definování obou disciplín a priorizaci slovenské a české jazykové oblasti. Ve studii identifikujme konvergentní a divergentní prvky sociální práce a sociální pedagogiky jako dvou jedinečných disciplín a profesí, přikláníme se $\mathrm{k}$ názoru, že sociální pedagogika je teoretičtější a všeobecnější, zatímco sociální práce je praktičtější a vědou více aplikovanou, avšak pro obě disciplíny je důležitá intenzivní spolupráce usilující předně o prevenci sociálně patologických jevů ve společnosti a vedoucí $k$ zdravému fyzickému, psychickému a sociálnímu vývoji jedince.
\end{abstract}

Klíčová slova: divergence, konvergence, sociální fungování, sociální pedagogika, sociální práce 


\section{Introduction}

The act of defining, in terms of linguistic semantic structure, makes an important statement about the nature of the research object. According to Strieženec $(2006, p .98)$, a definition is to be as complete as possible, yet at the same time the content is to be dense, and it should possibly form a single sentence. The definitions and defining of social work and social pedagogy constitute the central subject of this research, as they implicitly include the essence of social work and social pedagogy as perceived by professional and experts.

The most common approach in terms of conceptualisation of contemporary social work and social pedagogy is their understanding through the terminology used in different countries due to the fact that they are culturally conditioned. The proponents of this constructivist approach, in which scientific theories of social work or social pedagogy always depend on the social context, are for example M. Payne (2005), N. Thompson (2000, 2008, 2010), P. Navrátil $(2000,2001)$, and others. In contrast, Göppner and Hämäläinen $(2008$, p. 28 ) argue that such an approach tends to ignore the issues of epistemology and the theory of science.

The presented paper seeks to outline the convergent and divergent elements of social work and social pedagogy as two unique disciplines and practical activities. As convergent are seen those elements through which the two disciplines "converge" (from lat. vergo incline, bend, verge + cum together, with, in relation). The divergent elements are those through which the two disciplines "diverge", differ, or deviate from each other (from lat. divertó divert). By examining convergence and divergence of the two entities above, we will be able to identify, determine and describe the uniqueness and diversity of both disciplines.

\section{Research methodology}

The selected research topic is social work and social pedagogy in terms of their convergence and divergence. The research question was formulated as follows: "How is social work and social pedagogy defined by the contemporary Slovak, Czech, and selected foreign experts, while taking current legislation into account, and what convergent and divergent elements can be identified in the selected fields based on an analysis of their definitions?" The aim of the research is therefore to identify the convergent and divergent elements of social work and social pedagogy.

Qualitative research was chosen as the research strategy. The research instrument used was an analysis of documents using hermeneutic methods, mainly the content analysis. As the data selection method is of significance in a content analysis, and with regard to the research topic and objective, the following rules were applied when selecting the research sample:

- Literary sources must belong to one of the following types of documents:

- Dictionary or encyclopaedia, which explicitly define the terms "social pedagogy" and/or "social work."

- Monographs and textbooks of a collective character and providing the introductions, basics, theory, methodology and methods of social work and social pedagogy, which is explicitly stated in their tittle (journal articles, publications focused on selected target groups of social work, etc., were excluded from the research data sample).

- Legislative documents.

- The text must explicitly provide a definition, or a certain implicit character of defining must be evident. 
- In terms of content, we chose definitions which the authors of publication explicitly identify with, i.e., present them as their own (yet nested quotations of other authors' definitions were excluded).

- A representative sample with a local focus - primarily Slovak and Czech publications were chosen. Additionally, international context was also taken into consideration, therefore, publications from the Anglo-Saxon and German environment were also included in the research sample.

- As for the time perspective, material created after 1989 was selected due to significant changes in the socio-political systems of the Slovak and Czech Republics.

The research sample consisted of 67 sources, 55 were from the Slovak and Czech language area (26 of which were Slovak and 29 Czech), 9 were of the English origin and 3 of the German origin.

In the first stage, and with regard to research data management, content analyses of the examined terms "social work" and "social pedagogy" were conducted separately. Individual definitions were first separated into their elementary building blocks (entries) and semantic content units (phrases). The main categories were then distinguished within these elementary units and subcategories were assigned to them. Only in the second stage, did we compare the terms and content. The aim was to identify the common and different elements of both definitions within the selected categories.

Within the content-oriented defining, five basic categories emerged describing the essence of both disciplines studied:

1. Nature - What is social work? What is the nature of it?

2. Actors - Who performs it?

3. Object - Who / What is it performed for?

4. The nature of the activity itself - What are its goals, processes and tools used?

5. Field (resort) of functioning and conditions.

\section{Research results}

\subsection{Defining social work}

1. In the examined sample, we mainly watched for the terminology which the individual authors defined social work with, the content, and structure of the definition itself. Given THE NATURE of social work, it is possible to distinguish four basic subcategories with emphasis on the relationship among them.

I. Almost all definitions present social work as a profession. Such understanding is supported by the use of nouns activity, practice, activity and adjectives practical, specialised, professional a helpful. These often collocated in: practical activity (Matoušek, 2003; Žilová, 2005), practice (Tokárová et al., 2009), professional activity (Barker, 2003; Pierson \& Thomas, 2006; Tokárová et al., 2009), a form of professional help (OBDS, 2004), professional activity (Strieženec, 2001; Mátel \& Schavel, 2015), specialised activity (Act No. 219/2014 Coll., 2014), helping activity (Brnula et al., 2011).

II. Many definitions also present social work as a science. In addition to the term science, other nouns corresponded to this understanding of the term, e.g. discipline as well as a collocation scientific area (Levická, 2002) and scientific discipline (Žilová, 2005). The adjectives used either accentuated the scientific character of the discipline: a scientific discipline (Tokárová et al., 2009), a professional discipline (Strieženec, 1997; Mühlpachr, 2008; Novotná \& Schimmerlingová, 1992; Levická, 2002), or specified the area of science: social science 
Mátel \& Preissová Krejčí / Convergent and Divergent Aspects of Social Work ...

discipline (Matoušek, 2003) and its character: applied science (Barker, 2003; Mühlpachr, 2008; Mátel \& Schavel, 2015) applied scientific discipline (Žilová, 2005). The specific nature of social work as a science was presented by many authors in their multidisciplinary (e.g., Novotná \& Schimmerlingová, 1992), interdisciplinary (Tokárová et al., 2009) or pluridisciplinary nature (Žilová, 2005).

III. The latest trend is to emphasize social work as an academic discipline, or a field of education. Internationally, it is to do with the influence of the International Association of Schools of Social Work, which also reflected in the new global definition of IFSW (2014). Social work is also represented as an academic discipline in the research sample by Mátel and Schavel (2015).

IV. Many authors (Barker, Strieženec, Levická, Žilová, Tokárová and Mátel) emphasized the parallel of the two aspects of the nature of social work as a profession and a science. It is explicitly expressed by the American Dictionary of Social Work by the term empiricaltheoretical discipline (Barker, 2003), in Slovak by Strieženec (2006) and his theoretical and practical branch. Other definitions further describe the relationship between the two aspects of social work in parts of sentences, such as social work applies scientific knowledge into practical activities (Novotná \& Schimmerlingová, 1992; Strieženec, 1997; Mühlpachr, 2008; Mátel et al., 2011; Gulová, 2011). From the diachronic perspective it is the original idea of Novotná and Schimmerlingová (1992) that other authors have adopted and reproduced. A global definition of social work (IFSW, 2014) provides the following wording: social work is a profession based on the practice, and it is also an academic discipline. Mátel and Schavel (2015) emphasizes the connection between all three dimensions, namely that it is an applied scientific and academic discipline, and a professional activity of social workers.

2. With regard to social work as a profession and professional activity, many texts explicitly list ACTORS who perform this activity. The authors express a certain consensus that the actors can only be social workers. A classic statement attributed to a British author Neil Thompson (2000) claims that, "Social work is what social workers do." Some authors emphasize the professional basis of their activities (Strieženec, 1997, 2001; Mühlpachr, 2008; Levická, 2002), in Mátel et al. (2011) their qualifications, and Navrátil (2000) own professional community. Barker (2003) describes the connection between the scientific basis of the discipline and the work of social workers as a requirement of cognition or knowledge, and in IFSW (2014) supported by the theory. Due to the International Federation of Social Workers and its influence, social work has been seen as a profession based on values (Mátel et al., 2012), with a key role in this respect played by social workers. It is them who apply values and principles in their professional activity (Barker, 2003). Of particular principles/values of IFSW (2014) the following are emphasized: social justice (Thompson, 2010) and respect for human rights, and most recently, shared responsibility, and respect for diversity (IFSW, 2014). Based on the activity of social workers, some authors also provide a certain specific scope of their activities (Novotná \& Schimmerlingová, 1992; Tokárová et al., 2009), but for the purpose of this study we do not list the particular activities here.

3. THE OBJECTS of social work are not listed uniformly among the selected authors. Generally, we can distinguish two categories of objects of social work, which are the clients of social environments, or the relationship between them, which is often termed as social functioning.

I. The clients of social work can be referred to as the primary objects of social work in the studied texts. In the analysed definitions, these are referred to either in general as clients, or they are distinguished among. All authors who explicitly included clients in their definition of social work mean primarily individuals. Besides individuals, the term clients also includes other social systems (Sheafor et al., 2000; Gulová, 2011), mainly family, group, community. Some authors also explicitly list institutions (Strieženec, 1997; Mátel \& Schavel, 2015), and society is also listed among clients (Levická, 2002). With emphasis on the individual as the primary client 
of social work, it is necessary to pay increasing attention to human relationships and solving the related problems (IFSW, 2014; Navrátil, 2000; Mátel et al., 2011; Gulová, 2011). Mühlpachr (2008) emphasizes the integrity of a human and its preservation, while Navrátil (2000) introduces the concept of social roles. In addition to the primary objects that are viewed personally, objects of social work are also identified factually, through the concepts of social issues (Schilling \& Zeller, 2007; Matoušek, 2003), unfavourable social situation (Gulová, 2011), collision situations (Strieženec, 2006), serious difficulties/obstacles (Pierson \& Thomas, 2006), material and social need (Act No. 195/1998 Coll., 1998), a lack of (Mühlpachr, 2008) and dysfunctional elements (Strieženec, 2006), fulfilling their daily needs (OBDS, 2004).

II. The newest trend of contemporary social work is the emphasis on social environment (Barker, 2003; Tokárová et al., 2009; Mátel et al., 2011; Mátel \& Schavel, 2015; Sheafor et al., 2012), which significantly affects the lives of clients, as well as the working environment of social workers. These can be considered as the second category primary objects of social work. The term used for these categories are social conditions (Schilling \& Zeller, 2007; Matoušek, 2003).

III. The relationship between the clients of social work and their social environment is conceptualized by the term and the concept of social functioning in the studied definitions (Navrátil, 2000; Barker, 2003; Sheafor et al., 2012; Mátel \& Schavel, 2015), or psycho-social functioning (Barker, 2003; Mátel et al., 2011).

4. Based on THE NATURE OF THE ACTIVITY of social work itself, or of social workers' activity, we can distinguish the goals of social work, the process and tools by which the selected goals are achieved.

I. Goals - In this respect there is a relatively wide variety of goals within individual definitions, also depending on the type of objects of social work which they relate to:

- With regard to clients IFSW (2014) emphasizes strengthening, empowerment (Thompson, 2010; Mátel et al., 2011), liberation and enhancement of prosperity (Thompson, 2010). Due to the individual function of social work, the German authors Schilling and Zeller (2007) list assistance in self-determination and self-help, experience and support of one's personality. In Slovak conditions, the individuals' own responsibility is emphasized (Tokárová et al., 2009), as well as their security (Strieženec, 1997). The Collins Dictionary of Social Work mentions protection (Pierson \& Thomas, 2006). Matoušek (2003) uses help of social workers towards the clients in order to achieve the client's return into active life in the society. Brnula and others (2011), in their definition, work with the concept of quality of life. According to these authors, the goal of social work is to increase or stabilize the quality of life of people whose quality of life is threatened or limited, in a humane manner and so that the process of providing help is in accordance with their needs and ideas and so that it leads to self-help.

- With regard to social environment Barker (2003), Matoušek (2003) and Mátel et al. (2011) use creating favourable life conditions or social conditions, Tokárová et al. (2009) mitigating the environmental impact, and German authors Schilling and Zeller (2007) use a change in social conditions, or change of environment (Sheafor et al., 2012). In a similar way, IFSW (2014) and the American Dictionary of Social Work (Barker, 2003) set out social change as the objective of social work. At this point, it should be noted that German authors Schilling and Zeller (2007) explicitly mention focus on the European, world and social perspective, as well as human rights' perspectives and goals of social work.

- Regarding the interaction of clients with their social environment, their mutual adaptation, or improving mutual adjustment is accentuated as the goal (Tokárová et al., 2009). In the context of social functioning, the goal of social work is the improvement of social functioning (Sheafor et al., 2000; Barker, 2003), its renewal (Mátel et al., 2011), 
achieving its optimal (Mátel \& Schavel, 2015), sufficient (Barker, 2003) or maximum level (Sheafor et al., 2012). In the case of imbalance in social functioning, it is important that the clients are protected against difficulties (Sheafor et al., 2000).

II. The process of social work activities, or directly of social workers, is best viewed through identification of the verbs used. From the quantitative point of view, the verb help prevails, which corresponds with the other used terms of providing social assistance, helping people. Quite often in the texts, we find the verbs take care/caring (Strieženec, 1997, 2001; Levická, 2002; Pierson \& Thomas, 2006; Tokárová et al., 2009; Seithe, 2012), which is related to the close connection between social work and social pedagogy, especially in German authors. Therefore, one German definition also contains education (Seithe, 2012). In the newer concepts of social work, the term accompaniment prevails (Mátel \& Schavel, 2015), support (Pierson \& Thomas, 2006; Mátel et al., 2011) and strengthening/empowering (IFSW, 2014; Thompson, 2010; Mátel \& Schavel, 2015), which were cited above also as the goals of social work. Regarding the secondary objects of social work and in the context of social issues, the following verbs were detected: determine, identify, explain, mitigate, eliminate and solve (Matoušek, 2003; Tokárová et al., 2009; Gulová, 2011). The latter is also used in connection with the notion of conflict situations in the form of need for its solution (Strieženec, 2006). The term deficiency or lack collocates with removal (Mühlpachr, 2008) and prevention of its formation/prevention (Mühlpachr, 2008; Levická, 2002). Regarding social environment as another relevant primary goal of social work, predominately used verbs were: change (Schilling \& Zeller, 2007; Sheafor et al., 2012), improve (Schilling \& Zeller, 2007; Tokárová et al., 2009; Mátel et al., 2012), shape (Barker, 2003; Matoušek, 2003; Mátel et al., 2011), alleviate (Tokárová et al., 2009), protect (Sheafor et al., 2000; Pierson \& Thomas, 2006).

III. Tools - In their definition of social work, some authors also mention the tools to reach goals, or tools used by social workers in their professional practice. They usually do so by general naming special working methods (Strieženec, 2001; Levická, 2002; Mühlpachr, 2008). Some authors emphasize a specific method, for example counselling (Strieženec, 2001; Levická, 2002; Mühlpachr, 2008; Seithe, 2012); group work (Seithe, 2012), community work (Pierson \& Thomas, 2006) and advocacy (Pierson \& Thomas, 2006). The second group of instruments are services, whether organized social services (Levická, 2002), tangible services (Barker, 2003), social services (Barker, 2003; Gulová, 2011) or facilities (Seithe, 2012).

5. As for the FIELD or scope of action of social work, we can distinguish several areas where the profession of social work is exercised. In the Slovak Republic the primary area of social work is the field of labour, social affairs and family, which falls under the agenda of the Ministry of Labour, Social Affairs and Family of the Slovak Republic. Act No. 219/2014 Coll. (2014) regulates the exercise of the profession of social work exclusively in this area. The same holds true in the Czech Republic, where social work falls under the responsibility of the Ministry of Labour and Social Affairs and its exercise in the absence of professional Act is regulated by partial laws, especially the Act on Social Services (Act No. 108/2006 Coll., 2006).

In addition to this area, social work also pertains to the field of healthcare, justice, and to a limited extent to education, in both Slovak and Czech Republics. In the health sector it is still true that, "If $a$ medical facility is providing healthcare in the paediatric, geriatric, aftercare, psychiatric, drug addiction, gynaecology and obstetrics, or long-term care units, there must be a social worker employed in order to alleviate or remove the social consequences of the patient's health situation in connection with their hospitalization and release" (MZ SR, 2012). However, the above is a regulation whose status is below an act, therefore, it is often ignored in the Slovak and Czech practice.

As a result, the presence of social workers in health care facilities is still largely administrative, if they are present at all (Kuzníková et al., 2011, p. 20). In the Slovak Republic, social work is also performed in the field of justice, which covers mainly Corps of Prison and Court Guard. According to the 
regulation in force, "The performance of social work with the accused and sentenced is ensured by a social worker or a pedagogue authorised to perform social work" (Collection of orders, 2008). By this regulation, the social worker is understood as a qualified expert in the field of social work. However, the resort itself also allows other university educated professionals, including social pedagogues. In the Czech Republic and under the Ministry of Justice, social work is performed both in detention facilities (e.g. regulated by the Regulation of Director General of the Prison Service of the Czech Republic, Decree No. 109/1994, 1994) and as a probation and mediation service (defined by Act No. $257 / 2000$ Coll., 2000). The least favourable situation is in the Slovak education system, where a social worker is not officially included in the relevant legislation on pedagogical employees and professional employees, unlike a social pedagogue (Act No. 317/2009 Coll., 2009). In the Czech Republic, the position of a social worker in school facilities is most often legally recognised in counselling centres or in facilities for institutional and protective education (e.g. Children's homes, children's homes with schools, residential educational institutions and diagnostic institutions), while the profession of a social worker is not recognised by the Act on Educational Staff of the Czech Republic.

\subsection{Defining social pedagogy}

In the process of defining social work above, five basic categories emerged. The same categorization was applied when analysing texts concerning social pedagogy in order to allow for a comparison of both disciplines.

1. As for its NATURE, social pedagogy is seen either as a profession, science, academic discipline, or its theoretical and practical complements are also reflected within the definitions.

I. Social pedagogy is often associated with science in the analysed publications. In this sense, the following terms are used: discipline (Procházka, 2012), scientific branch (Bakošová, 2005), professional discipline (Matoušek, 2003). Its pedagogical side was usually accentuated: pedagogical discipline or teaching science (Kolář et al., 2010; Kraus, 2008; Kraus et al., 2001). However, emphasis was also placed on its interdisciplinarity: a multidisciplinary field (Sekot, 1997), an interdisciplinary scientific branch (Soják \& Čech, 2010), trans-disciplinary science (Kraus et al., 2001), the science bordering between pedagogy and sociology (Tománek, 2013).

II. Social pedagogy rarely appears as a profession in the analysed definitions. As for the terms used, the following nouns correspond with this notion of social pedagogy: activity, process, practice, and collocations such as an educational process (Kraus, 2008), public care (Schilling, 1999), socially significant practice (Hrdá \& Šíp et al., 2011), leisure activities (Kraus, 2008; Lorenzová \& Poláčková, 2001), preventive action (Kraus, 2008).

III. The nature of social pedagogy also defines its concept as an academic discipline, field of study or academic activity. As with social work, such a characteristic is more of a recent trend and is characterized, for example, by definitions of L. Gulová (2011), M. Procházka (2012) or J. Němec et al. (2010). In Slovakia, social pedagogy in not a separate study programme, as opposed to social work, and is taught as a subject within the study programme of pedagogy. In the Czech Republic, although "some universities have programmes of social pedagogy, most of their subjects draw from social work" (Gulová, 2011, p. 71).

IV. The authors of the analysed texts in their definitions most often emphasize the parallel theoretical and practical parts of social pedagogy. Social pedagogy as a member of humanities has its theoretical and practical sides that cannot be separated (Manniová, 2005; Gulová et al., 2012; Hrdá \& Šíp et al., 2011). Similarly the Dictionary of Andragogy defines social pedagogy as a discipline of pedagogical science and at the same time as a field of practice (Průcha \& Veteška, 2012, p. 232).Terminological glossary of social pedagogy defines social pedagogy as $a$ science examining the social objectives of education and also as a socio-educational and preventive action (Bakošová et al., 2013; cf. Hroncová et al., 2000). Other authors speak of 
applying the expertise of social pedagogy in practice (Klíma, 1993) or an analysis of social factors and implementing procedures (Matoušek, 2003).

2. The definitions of social pedagogy are formed with respect to its ACTORS. Across the analysed publications, an actor is a social pedagogue, distinguished from a social worker (Kolár et al., 2010). A social pedagogue is seen as a graduate in the given field, who is professionally prepared to work in different areas of the social sphere (Bakošová et al., 2013; Soják \& Čech, 2010). Some authors placed social pedagogues in schools where they serve as assistants and advocates of students (Lorenzová \& Poláčková, 2001), contributing to a healthy socio-psychological climate of the school (Kraus, 2008), professionally supporting teachers in schools at the level of education, prevention, intervention, etc. (Soják \& Čech, 2010) and providing social assistance with pedagogical orientation (Hrdá \& Šíp et al., 2011).

3. Social pedagogy is delineated by its OBJECTS. As in the case of social work, objects can be both clients (individuals and groups) or the social environment and the relationship between them. Children are usually considered clients of social pedagogy with various adjectives often added: vulnerable children (Matoušek, 2003), children of poor and young people (Schilling, 1999), disadvantaged children, Roma children or children of immigrants (Gulová et al., 2012), children from vulnerable families (Průcha, Walterová, \& Mareš, 2001; Průcha \& Veteška, 2012). Some authors, however, point out the need to view children/pupils as members of various social groups (Hradečná, 1998). Different social groups thus become clients of social pedagogy: family, peer groups, interest groups of extracurricular activities, school (Přadka et al., 1998; Hroncová \& Emmerová, 2004). Therefore, in addition to children and adolescents, adults are then considered clients, including the endangered population as well as the whole society in terms of creating a balance between the needs of the individual and society (Bakošová et al., 2013; Kraus et al., 2001). In the broadest sense, every human can become the object of social pedagogy (Balvín \& Prokaiová, 2013; Strieženec, 1999).

Due to the position of social pedagogy within pedagogical sciences, all participants in the educational process tend to be labelled as clients of social pedagogy, i.e. not only students but also teachers, school headmasters and other staff in the school. Regarding the social environment, its impact on education becomes an object of social pedagogy (Průcha \& Veteška, 2012), social factors threatening human development (Matoušek, 2003), pedagogically valuable stimuli (Bakošová, 1994), the social aspects of education and personality development (Hroncová et al., 2000), generally termed as conditions of education (Kolář et al., 2010) or a wide range of issues "connected with the educational influence on risk and socially disadvantaged group of youth and adults: dysfunctionalities in family and parenting, foster care, the issue of abused, neglected, and sexually abused children, social deviation including delinquency and aggression, drug abuse, child prostitution, pornography and the like." (Průcha, Walterová, \& Mareš, 2001, p. 217).

4. The NATURE of the activity of social pedagogy itself, can be analysed with regard to its goals, processes and tools.

I. The most important factor in determining the goals of social pedagogy is a prerequisite of a relation between the social environment and education. Social pedagogy is to deal with the negative social phenomena that threaten the society (Manniová, 2005). Emphasis is placed on rectification or optimisation of relation conditions between the client and the environment (Bakošová et al., 2013; Bakošová, 2008; Balvín \& Prokaiová, 2013; Kolář et al., 2010; Průcha, 2009; Strieženec, 1999), assistance in various social problems (Bakošová, 2008, 1994; Kraus et al., 2001). More specifically, the goals of social pedagogy can be seen in activation of the socially disadvantaged groups (Gulová et al., 2012) or in interdisciplinary research (Hrdá \& Šíp et al., 2011). Most authors logically emphasize the goals connected with the educational process, e.g. changing people through education (Bakošová, 2008), analysis of the conditions of 
education that help or hinder the achievement of the goals of education (Kolár et al., 2010), or professional training of social pedagogues for school practice (Gulová et al., 2012).

II. Similarly to social work above, in the case of social pedagogy an analysis of verbs will be used to help understand the process of activity of social pedagogy. As for frequency, the most important activities of social pedagogy are: preventing negative social events or prevention (Schilling, 1999; Hroncová et al., 2000; Sekot, 1997; Němec \& Vodičková, 2010; Kraus, 2008; Soják \& Čech, 2010; Bakošová et al., 2013). Equally important are educational and reeducational activities (Sekot, 1997; Soják \& Čech, 2010; Průcha, Walterová, \& Mareš, 2001; Gulová et al., 2012), as well as resocialization (Procházka, 2012; Průcha, Walterová, \& Mareš, 2001; Hroncová \& Emmerová, 2004; Kraus, 2008), integration (Bakošová, 1994, 2008; Tokárová et al., 2000; Sekot, 1997) and intervention (Hroncová \& Emmerová, 2004; Bakošová et al., 2013). Social pedagogy purposefully influences humans (Kolář et al., 2010; Strieženec, 1999; Bakošová, 1994). In relation to negative social phenomena, the following verbs are used: protect (Schilling, 1999), compensate (Bakošová, 1994), create balance and stabilize (Kraus et al., 2001; Bakošová, 2008), educate and utilise the goals of education (Kolář et al., 2010; Klíma, 1993; Kraus, 2008; Bakošová, 2005, 2008), deal with crisis situations (Hroncová \& Emmerová, 2004), influence or initiate changes (Matoušek, 2003; Schilling, 1999; Soják \& Čech, 2010), clarify (Bakošová, 2005).

III. Among the tools of social pedagogy mentioned in the definitions rather less frequently, are the procedures and methods that are to balance the adverse effect of social influences (Matoušek, 2003), such as various preventive and curative measures (Schilling, 1999). According to Z. Bakošová et al. (2013), the following instruments belong among the tools of social pedagogy: education, re-education, self-education, counselling, prevention, intervention and management.

5. Regarding the FIELD of action of social pedagogy, several areas can be distinguished for this profession to be exercised. The primary areas of the activity of social pedagogues in Slovakia, is the area of education. According to the Act No. 317/2009 Coll. (2009), a social pedagogue belongs in the category of professional staff. According to this law, a social pedagogue "carries out professional activities in prevention, intervention and counselling especially for children and pupils at risk of socio-pathological phenomena, from socially disadvantaged backgrounds, drug addicts or otherwise disadvantaged children and pupils, to their legal guardians and pedagogical representatives of schools and educational facilities. A social pedagogue fulfils the roles of social education, support of pro-social, ethical behaviour, socio-pedagogical diagnostics of environment and relationships, socio-pedagogical counselling, prevention of socio-pathological phenomena, and re-education of behaviour. They also perform expert and public educational activities" § 24 (Act No. 317/2009 Coll., 2009). Furthermore, they may also act in the field of labour and social affairs and family in execution of the selected activities, such as when exercising socio-legal child protection. Relatively large competencies can be gained in the area of justice, particularly in the penitentiary practice. In the current Slovak penal and judicial system, a person on a position of a "pedagogue" amasses a fairly high level of competences and responsibility when dealing with the accused and convicted.

Among other activities, a pedagogue proposes a treatment program, provides the convict with a list of activities that are organized in the facility; coordinates and facilitates the treatment of convicts in the selected area, while managing a comprehensive agenda with decision-making rights regarding disciplinary action against the convicts (Decree No. 368/2008 Coll., 2008). In the Czech Republic, a similar delineation of the scope of activity of a social pedagogue is missing. It is defined only in the area of social services, namely under $\S 110$ (Act No. 108/2006 Coll., 2006), which states that it is sufficient for the professional competence of a social worker to complete an educational programs focused on social work and social pedagogy. 


\subsection{Comparison of convergent and divergent elements}

Convergence in terms of nature. Social work and social pedagogy are interdisciplinary-oriented fields, independent helping professions and academic disciplines.

Divergence in terms of nature. In terms of the scientific nature, social pedagogy is a more theoretical and more general discipline, while social work is a more practical and applied discipline. Social work in Slovakia is a separate scientific and study field, while social pedagogy is rather a subspecialty of pedagogy and is taught at universities merely within a study programme of pedagogy. Social work belongs among social-behavioural sciences, social pedagogy among pedagogical sciences.

Convergence in terms of actors. Social work and social pedagogy are performed exclusively by qualified staff.

Divergence in terms of actors. In most countries, social work is exclusively carried out by social workers with a university degree in social work. Social pedagogy is performed by social pedagogues with a university degree in social pedagogy. The qualification requirements, however, are socio-politically conditioned, and in certain cases, rather vaguely set. For example, in the Czech Republic social work can be performed by persons educated in social pedagogy, and even without university education (Act No. 108/2006 Coll., 2006) as the professional competence of a social worker is: higher vocational education, university education or completion of accredited training courses with particular focus, for example in the following fields: social policy, social and humanitarian work, social pathology, special education, etc.

Convergence in terms of objects. The objects of the action of the two disciplines are not just clients (individual, family, group, community, institution), but also the influence on the social environment in which they exist.

Divergence in terms of objects. The individual disciplines have different preferences of clients, yet the range of both is very wide. Social pedagogy prefers school and non-school environment, and in terms of age, it works mainly with children and youth. Social work is provided to a greater extent to adults and seniors, and in addition to its field or outreach forms, it is exercised in the natural environment of the clients (in the family, community, open environment), as well as in the outpatient and residential settings, especially in social service facilities. Matoušek differentiates between both disciplines on the basis of their target groups as follows: social work as work with adults, while social pedagogy as prevention of social failure among children and youth (Matoušek, 2003), while Machalová through the concept of "preventive social work" sees educational social work as a border discipline of findings and methods intertwined with social pedagogy and social andragogy. The concept of educational social work and counselling is seen as a lifelong process, as a sub-discipline of social work, which aims to "develop and cultivate individual spiritual, mental and social potential of individuals" of the target groups of social work (Machalová, 2013, pp. 24-25).

Convergence in terms of the nature of the activity. For both professions, it is rather symptomatic to cover a broad spectrum of different activities and to manifest a holistic approach, using various yet common methods and procedures, especially prevention, re-socialization, counselling and mediation.

Divergence in terms of the nature of the activity. Social pedagogy prefers mainly socio-educational, preventive and re-educational activities. Social work uses various, own methods of work, such as case, group, and community social work, street work and family social work.

Convergence in terms of the field or scope of activity. Both professions operate in several areas. The common areas are labour, social affairs and family, and justice. 
Divergence in terms of the field or scope of activity. The primary areas of activity of social work is the resort of labour, social affairs, and family. The primary areas of activity of social pedagogy is education. While in the Slovak Republic social workers work in education, they do so without legislative anchoring. Unlike social workers, social pedagogues do not work in the healthcare area.

\section{Discussion and conclussion}

The relationship of social pedagogy and social work is historically and culturally conditioned. According to the German professor Johannes Schilling (1999), we can distinguish several models from the historical perspective:

- Subordination - the proponents of this model argue which is a superior term, social pedagogy or social work.

- Substitution - arbitrary interchangeability of the two terms, i.e. no distinction between them.

- Identity - identical disciplines as in "two sides of the same coin".

- $\quad$ Alternative - both expressions are well established and can be used as alternatives.

- Convergence - mutual approximation of both disciplines while preserving their own identity.

- Subsumption - a double concept of social pedagogy/social work, or seeking an umbrella term for both, e.g., social services.

Schilling (1999, p. 140) inclines towards convergence: "Social pedagogy and social work are not two completely different fields, but they are neither completely identical. We can imagine them joined together into one unit. Such convergence does not refer to tasks, decomposition, or a composition of the areas. Instead, it refers to a joint development of social pedagogy and social work towards a growing agreement, while taking into account their independence and individuality." In Germanspeaking countries in the area of education, it has been acknowledged for decades, that the areas of Sozialarbeit (or Soziale Arbeit) and Socialpädagogik were very closely linked, to the point of being identical.

According to Kraus (2008, cf. Ondrejkovič, 2000), there are three main views on the relationship between the two disciplines in our settings:

- Identifying - practically means identification of both disciplines, metaphorically expressed as "two sides of the same coin," typical for German-speaking countries.

- Differentiated - both disciplines are clearly separated historically and on the basis of the objects of their research. It is typical for the Anglo-Saxon area, and also applies in the Czech Republic. In this regard, Kaplánek (Matoušek et al., 2013) states that mutual "passing by" of social pedagogy and social work in the Czech theory and practice is not only due to different theoretical approaches. The fundamental problem is the strict separation of social work and pedagogy in practice on the basis of valid legislation.

- Convergent - means integration, while maintaining a certain uniqueness of both disciplines. According to Kraus, it is practiced in Slovakia and Poland. Yet, in this respect we disagree with Kraus. We believe that the current Slovak social work practice is dominated by the AngloSaxon differentiation model, with the exception of schools (e.g., UMB Banská Bystrica) and representatives, who professionally originate from social pedagogy and therefore at least theoretically strive for convergence of both disciplines (e.g., Ondrejkovič, Bakošová, Hroncová and Machalová).

Based on the study, we are inclined to think that it is possible to distinguish between convergent and divergent elements of both professions that are understood as separate (differentiated) professions, disciplines and fields of study in the Slovak Republic and the Czech Republic. We agree with Hroncová 
(In Kraus, 2008) according to whom, social pedagogy is more theoretical and more general, while social work is more practical and a more applied science.

Due to many convergent elements, intensive cooperation between the two is crucial. A relationship between the two disciplines is described as cooperative, for example by Žilová (2005). Both disciplines have their own field of exact development and scope of activity in relation to the joint entity of their subject that is defined by the specificity of their goals in relation to the target focus - a healthy physical, psychological and social development of the individual. Naturally, this requires a reciprocal use of theoretical knowledge, findings, generalization of empirical researches and mutual adaptation and utilization of methods of work, i.e. cooperation on the principle of acceptance, mutual respect and cooperation with other border disciplines. Due to interdisciplinary collaboration between social pedagogy and social work in the area of prevention of socio-pathological phenomena, Bakošová (In Ondrejkovič, 2009, p. 489) aptly notes that "the two disciplines will fare better if they offer effective prevention programmes that are systematic, planned, long-term and will lead not only to new behaviour practice, but also to their internalisation."

\section{Literature}

Act No. 108/2006 Coll., on social services. (2006). Retrieved from http://www.mpsv.cz/files/clanky/7372/108_2006_Sb.pdf

Act No. 195/1998 Coll., on social help. (1998). Retrieved from http://www.noveaspi.sk/products/lawText/1/46814/1/2

Act No. 219/2014 Coll., on Social work and of the conditions for the exercise of certain professional activities in the field of social and family affairs, and on amendments to certain acts. (2014). Retrieved from http://www.zbierka.sk/sk/predpisy/219-2014-z-z.p-35788.pdf

Act No. 257/2000 Coll., on probation and mediation service. (2000). Retrieved from http://aplikace.mvcr.cz/sbirka-zakonu/ViewFile.aspx?type=c\&id=3462

Act No. 317/2009 Coll., on professional and pedagogical employees and professional employees and on the change and supplement to some acts. (2009). Retrieved from http://www.zbierka.sk/sk/predpisy/317-2009-z-z.p-33092.pdf

Bakošová, Z. (1994). Sociálna pedagogika (Vybrané problémy). Bratislava: Univerzita Komenského v Bratislave.

Bakošová, Z. (2005). Sociálna pedagogika ako životná pomoc. Bratislava: Univerzita Komenského v Bratislave.

Bakošová, Z. (2008). Sociálna pedagogika ako životná pomoc. Bratislava: Univerzita Komenského v Bratislave.

Bakošová, Z. (Ed.). (2013). Terminologický výkladový slovník zo sociálnej pedagogiky. Trnava: Univerzita sv. Cyrila a Metoda v Trnave.

Balvín, J. \& Prokaiová, J. (2013). Pedagogické a filozoficko-etické aspekty sociální práce, sociální pedagogiky a andragogiky. Praha: Hnutí R.

Barker, R. L. (2003). The social work dictionary. Washington, DC: NASW.

Brnula, P., Gabura, J., Labáth, V., \& Vaska, L. (2011). Sociálna práca - dve dekády existencie študijného odboru sociálna práca. In Quo vadis, univerzitné vzdelávanie, veda a výskum na pedagogických fakultách? Bratislava: Univerzita Komenského v Bratislave.

Collection of orders of the General Directorate of the Corps of Prison and Court Guard. The order No. 60 on Social work in the Corps of Prison and Court Guard. (2008). Retrieved from http://www.zvjs.sk/dokumenty/legislativa/2014/legislativnenormy/RGR60_2008.pdf 
Decree No. 109/1994 Coll., Decree of the Ministry of Justice of the Slovak Republic. (1994). Retrieved from http://www.vscr.cz/client_data/1/user_files/19/file/PDF/V\%C3\%BDkon\%20v\%C4\%9Bze\% C5\%88stv\%C3\%AD/109-1994.pdf

Decree No. 368/2008 Coll., Decree of the Ministry of Justice of the Slovak Republic. (2008). Retrieved from http://www.zakonypreludi.sk/print/zz/2008-368/znenie-20160101.pdf

Göppner, H. J., \& Hämäläinen, J. (2008). Rozprava o vede o sociálnej práci. Hladanie prvkov pre programatiku. Bratislava: VŠZaSP sv. Alžbety.

Gulová, L. (2011). Sociální práce. Praha: Grada Publishing.

Gulová, L. (Ed.). (2012). Aktivizace sociálně znevýhodněných skupin v pedagogické praxi a výzkumu. Brno: Masarykova univerzita.

Hradečná, M. (1998). Vybrané problémy sociální pedagogiky. Praha: Karolinum.

Hrdá, M., \& Šíp, R. (Eds.). (2011). Identita v sociálně pedagogickém výzkumu. Role napětí, změn a začlenění. Brno: Masarykova univerzita.

Hroncová, J., \& Emmerová, I. (2004). Sociálna pedagogika. Banská Bystrica: Univerzita Mateja Bela $v$ Banskej Bystrici.

Hroncová, J., Hudecová, A., \& Matulayová, T. (2000). Sociálna pedagogika a sociálna práca. Banská Bystrica: Univerzita Mateja Bela v Banskej Bystrici.

International Federation of Social Workers (IFSW). (2014). Global definition of social work. Retrieved from http://ifsw.org/get-involved/global-definition-of-social-work

Klíma, P. (1993). K epistemologickým a metodologickým zdrojům sociální pedagogiky. Éthum, 3-11.

Kolář, Z. (Ed.). (2010). Sociální pedagogika. Praha: Univerzita Karlova v Praze.

Kraus, B. (Ed.). (2001). Člověk - prostredí - výchova: K otázkám sociální pedagogiky. Brno: Paido.

Kraus, B. (2008). Základy sociální pedagogiky. Praha: Portál.

Kuzníková, I. (Ed.). (2011). Sociální práce ve zdravotnictví. Praha: Grada Publishing.

Levická, J. (2002). Teoretické aspekty sociálnej práce. Trnava: ProSocio.

Lorenzová, J., \& Poláčková, V. (2001). Specifika pomáhání v podmínkách školy. In B. Kraus (Ed.), Člověk - prostredí - výchova: Kotázkám sociální pedagogiky (pp. 190-198). Brno: Paido.

Machalová, M. (2013). Preventívna sociálna práca: Edukačná paradigma v sociálnej práci. Prešov: Prešovská univerzita.

Manniová, J. (2005). Úvod do pedagogiky. Bratislava: Axima.

Mátel, A. (Ed.). (2012). Etika sociálnej práce. Bratislava: Vysoká škola zdravotníctva a sociálnej práce sv. Alžbety.

Mátel, A., \& Schavel, M. (2015). Teória a metódy sociálnej práce I. Bratislava: Spoločnost' pre rozvoj sociálnej práce.

Mátel, A., Oláh, M., \& Schavel, M. (2011). Vybrané kapitoly z metód sociálnej práce I. Bratislava: VŠ ZaSP sv. Alžbety.

Matoušek, O. (2003). Slovník sociální práce. Praha: Portál.

Matoušek, O. (Ed.). (2013). Encyklopedie sociální práce. Praha: Portál.

Ministry of Health of the Slovak Republic (MZ SR). (2012, December 27). Bulletin of the Ministry of Health of the Slovak Republic. Retrieved from 
http://www.health.gov.sk/Zdroje?/Sources/dokumenty/vestniky_mz_sr/2012/vestnik-39-602012.pdf

Mühlpachr, P. (2008). Úvod do sociální práce. Brno: VŠ ZaSP sv. Alžbety v Bratislave.

Navrátil, P. (2000). Úvod do teorií a metod sociální práce. Brno: Národní centrum pro rodinu.

Navrátil, P. (2001). Teorie a metody sociální práce. Brno: Marek Zeman.

Němec, J. (Ed.). (2010). Výzkum zaměřený na...: Základní směry výzkumu Katedry sociální pedagogiky PdF MU. Brno: Masarykova univerzita.

Němec, J., \& Vodičková, M. (2010). Výzkum zaměřený na základní oblasti sociální pedagogiky. In J. Němec (Ed.), Výzkum zaměřený na...: Základní směry výzkumu Katedry sociální pedagogiky PdF MU. Brno: Masarykova univerzita.

Novotná, V., \& Schimmerlingová, V. (1992). Sociální práce, její vývoj a metodické postupy. Praha: Karolinum.

Ondrejkovič, P. (2000). Príspevok k otázkam vztahov sociálnej pedagogiky a sociálnej práce. Pedagogika, 50(2), 181-191.

Ondrejkovič, P. (Ed.). (2009). Sociálna patológia. Bratislava: Veda.

Österreichischen Berufsverbands für Sozialarbeiterlnnen (OBDS). (2004). Berufsbild der Sozialarbeiterlnnen. Wien: OBDS.

Payne, M. (2005). Modern social work theory. Basingstoke: Palgrav Maccmillan.

Pierson, J., \& Thomas, M. (2006). Collins dictionary of social work. Glasgow: HarperCollins.

Procházka, M. (2012). Sociální pedagogika. Praha: Grada Publishing.

Průcha, J. (Ed.). (2009). Pedagogická encyklopedie. Praha: Portál.

Průcha, J., \& Veteška, J. (2012). Andragogický slovník. Praha: Grada Publishing.

Průcha, J., Walterová, E., \& Mareš, J. (2001). Pedagogický slovník. Praha: Portál.

Přadka, M., Knotová, D., \& Faltýsková, J. (1998). Kapitoly ze sociální pedagogiky. Brno: Masarykova univerzita.

Seithe, M. (2012). Schwartzbuch Soziale Arbeit. Wiesbaden: VS Verlag. doi:10.1007/978-3-53192271-3_6

Sekot, J. (1997). Sociální pedagogika jako vědní disciplína a studijní obory v ČR. Závěrečná zpráva programu PHARE. Praha: VPŠ.

Sheafor, B. W., \& Horejsi, Ch. R. (2012). Techniques and guidelines for social work practice. Boston: Allyn and Bacon.

Sheafor, B. W., Horejsi, Ch. R., \& Horejsi, G. A. (2000). Techniques and guidelines for social work practice. Boston: Allyn and Bacon.

Schilling, J. (1999). Sociálna práca. Hlavné smery vývoja sociálnej pedagogiky a sociálnej práce. Trnava: SAP.

Schilling, J.,\& Zeller, S. (2007). Soziale Arbeit. München: Ernst Reinhard Verlag.

Soják, P., \& Čech, T. (2010). Cesta do školy aneb Výzkum potřebnosti a uplatnitelnosti sociálního pedagoga ve škole. In J. Němec (Ed.), Výzkum zaměřený na..: Základní směry výzkumu Katedry sociální pedagogiky PdF MU. Brno: Masarykova univerzita.

Strieženec, ̌̌. (1997). Slovník sociálneho pracovníka. Trnava: AD. 
Mátel \& Preissová Krejčí / Convergent and Divergent Aspects of Social Work ...

Strieženec, Š. (1999). Úvod do sociálnej práce. Trnava: AD.

Strieženec, Š. (2001). Úvod do sociálnej práce. Trnava: Tripsoft.

Strieženec, Š. (2006). Teória a metodológia sociálnej práce. Trnava: Tripsoft.

Thompson, N. (2000). Understanding social work: Preparing for practice. Basingstoke: Palgrave.

Thompson, N. (2008). Practising social work: Meeting the professional challenge. Basingstoke: Palgrave.

Thompson, N. (2010). Theorizing social work practice. Basingstoke: Palgrave Macmillan.

Tokárová, A. (Ed.). (2009). Sociálna práca. Prešov: Akcent print.

Tománek, P. (2013). Základy andragogiky a rodinnej výchovy pre sociálnych pracovníkov. Brno: Tribun EU.

Žilová, A. (2005). Úvod do teórie sociálnej práce. Badín: Mentor. 